\title{
A public practical theological theory for religious education of secularised
}

\author{
youth
}

\author{
Yolanda Dreyer \\ Department of Practical Theology \\ University of Pretoria
}

\begin{abstract}
In the postmodern world young people no longer accept the values advocated by the institutionalised church as unquestionably relevant to their lives, one of the reasons for this being that the supremacy of the Christian faith has given way to a secularised society. Public practical theology includes the public as one of its audiences. In this paper the point of departure is a reflection-theory and not the praxis as such. This theory focuses on everyday concerns and issues in order to facilitate a dialogue between theology and the social sciences. The article aims to reflect on the enhancement of the experience of transcendence in the everydayness of the present-day youth. It argues that the agency theories of Anthony Giddens and Pierre Bourdieu can provide a theoretical basis and method for public religious education.
\end{abstract}

\section{INTRODUCTION}

"Public theology" is a fairly recent term referring to a theology which critically reflects on both the Christian tradition as well as social and political issues. This dialogue is seen to benefit both theology and society. Models of public theology have been developed by David Tracy ([1975] 1996) and Ronald Thiemann (1991) (see Browning \& Francis Schüssler Fiorenza 1992). Not all practical theology is public theology, in other words aimed at a non-ecclesial general audience. Practical theology is also theology for the church, that is for a Christian audience, and is theology for an academic audience.

Nevertheless, one of the tasks of practical theology is to include the public dimension in its work (Osmer \& Schweitzer 2003:215). The days are long gone when the practices of the church and clergy were the main (only) focus of practical theology. The vision has broadened to include the context of everyday life on a local, national and global level. The task of practical 


\section{A public practical theological theory for religious education of secularised youth}

theology in this regard is "bringing theology into dialogue with contemporary culture" (Osmer \& Schweitzer 2003:216; cf Schweitzer 1991a). The idea of "public church" (cf Marty 1981; Palmer 1981; Huber 1979, 1998) was utilised in practical theology by James Fowler $(1987,1991)$. He emphasises that the focus of the church community should be on the common good, on a personal as well as a structural-societal level (see Osmer \& Schweitzer 2003:218). According to Don Browning (1991:36), practical theology should be based on "a critical reflection on the church's dialogue with Christian sources and other communities of experience and interpretation with the aim of guiding its action toward social and individual transformation." The task of a public practical theology is threefold: to include the public as one of the audiences of practical theology; to include everyday concerns and issues in its reflection; to facilitate a dialogue between theology and contemporary culture (see Osmer \& Schweitzer 2003:218). This paper aims to reflect on:

- $\quad$ The public context of present-day youth

- A public practical theological theory to engage with the fields of modernity and postmodernity

- $\quad$ The enhancement of the experience of transcendence in everydayness.

The paper will argue that agency theory and therefore a multidisciplinary practical-theological method can provide a theoretical basis for public religious education.

\section{THE PUBLIC CONTEXT OF PRESENT-DAY YOUTH}

\subsection{The situation of the modern Western world}

The currently crisis of the church in the Western world is that people are becoming less involved with the church as institution. Recently Jacques Janssen (2003) and Richard Osmer \& Friedrich Schweitzer (2003), among others, investigated the conditions of the present-day youth in this context. In Europe church membership and attendance are decreasing steadily. All indications point to religion as an institution being on the decline. Since the 1970s the Netherlands has been forging ahead in this process of secularisation (cf Becker \& Vink 1994; Dekker, Hart \& Peters 1997; Felling, Peters \& Schreuder 1991; Janssen 1998:101-113; Bernts 1995; De Hart 1994; Linden 1989; Van der Ven \& Biemans 1994; Janssen \& Prins 2000:3148). 
According to statistics provided by Janssen (2003:4), 40\% of the Dutch population was Catholic in 1945. That number has since halved and the projection is that by 2023 it will have dwindled to some 15\%. In $194515 \%$ of the population did not belong to any religious denomination. Today this group comprises $60 \%$ of the population and the prediction is that by 2020 it will have reached $70 \%$. Throughout Europe the scores of the younger generation are lower than those of older people on virtually every indicator for religious behaviour (Janssen 2003:4). The 1990 study, Europese Waarden Onderzoek, indicated that $53 \%$ of the Dutch youth did not belong to a church. This was the highest percentage in Europe (Janssen 2003:4). In countries such as Ireland and Italy the majority of the youth still belongs to the church, but even in those countries the numbers are declining. This is also the case in the United States (see Kosmin, Mayer \& Keysar 2001).

Sociologists see the tendency of the decline of the institutional church as the last phase in the process of secularisation (Janssen 2003:5). For Jürgen Habermas $(1981,1987)$ this process is part of modernity's "unfinished task". The church has little influence on matters such as science and politics, social issues, matters of everyday life and death. People are educated and free to make their own decisions. They live according to their own insights and out of their own strength (cf Wilson 2000). However, as churches find themselves in a crisis, so also do humanistic, agnostic and atheistic institutions. In the sixties many young people were inspired by the political movement of democratic socialism. This movement has now lost its power. Socialist parties have difficulty explaining how their message is unique and worthwhile (cf Bell 1960). Scepticism functions as an alternative orientation to life (Janssen 2003:5).

Yet, at this point people are becoming increasingly interested in spirituality. The New Age movement with its amalgam of religious products, is pursued by many. This tendency was already pointed out in 1802 by Francois René de Chateaubriand who described it as follows: "When people believe in nothing anymore, they start believing in everything; where they previously had prophets, they now want seers, where they once had religious ceremonies, they now want magic, and after the temples of the Lord had been closed down, they seek a home with enchanters." The Netherlands which is at the forefront of secularisation, is at the same time the European country where experimental religiosity abounds (cf Becker, Hart \& Mens 1997). Since the 1960s social scientific research in the United States has divulged the following pattern: high involvement with the church during childhood; less involvement during adolescence; adolescents and young adults leaving the church; a small number returning to the church in their late twenties and early thirties (Osmer 


\section{A public practical theological theory for religious education of secularised youth}

\& Schweitzer 2003:xii; cf Roof \& McKinney 1987; Hoge, Johnson \& Luidens 1994; Hoge 1981; Oswald \& Leas 1987). The pivotal period seems to be adolescence. Research has shown that confirmation often marks the end of young peoples's involvement with the church (see Benson \& Eklin 1990). In Germany not much religious education is offered to children and only a small number participates in Sunday school (see Schweitzer 1991b). This places much pressure on confirmation classes, after which the young people also tend to leave the church (Osmer \& Schweitzer 2003:xiii; cf Schweitzer 1996). Religion is taught in public schools in Germany and most children do receive this education. It is, however, not enough to induce them to join or remain in a church.

In the United States and Europe the changes of modernity took place from the eighteenth to the twentieth centuries. These changes include industrialisation, capitalist and market economies, urbanisation, technological developments and the institutionalisation of systems of education, medicine and social welfare (Osmer \& Schweitzer 2003:35; cf Eisenstadt 1966; Coleman 1968:395-402).

In the Netherlands too, church attendance, religious education and confirmation have become the exception rather than the rule (see Dingemans [1986] 1991:27). The reason for this is that the supremacy of the Christian faith has given way to a secularised society in which the church has been marginalized. The Christian faith has been relativised as other faiths, worldviews and ideologies gained ground. The answers to life's deeper questions are no longer found in the Christian faith, and the church has lost its authority and influence. This means that the values advocated by the institutionalised church are no longer accepted by young people as unquestionably relevant to their lives (Dingemans 1991:27).

Characteristics of young people today are that they have more knowledge their parents by means of which they find their own meanings. They are used to having money and spend freely. They are conscious of fashion and trends and this is exploited by commerce. Music is an important element of their subculture by means of which they place themselves over against the established culture. They are "other-directed" and respond in a flexible way to what their environment offers. All of this contributes to uncertainty. They cannot afford to be "out". There is also uncertainty concerning work and job opportunities for young people. The future does not seem particularly rosy. Issues facing people today can be overwhelming and no ready answers are available (see Dingemans 1991:32-33).

For some, religion criticism and ideology criticism are central to the process of secularisation. Religion has long been the façade behind which 
cultural religion and a capitalist society with its class differences and exploitation have been hiding (cf Ter Schegget 1981). God was seen as the power sanctioning the status quo. Feuerbach, Freud and Marx criticised this and with their image of "the oppressive God" the idea of the "liberating God" was lost. Church structures and mores have obscured the view on the God of peace and justice for all. Therefore secularisation is a process of purging the church of its misuse of the name of God. Dingemans (1991:40) puts it as follows: "Misschien kunnen wij - door de godsdienstkritiek heen - dan weer zicht krijgen op de bevrijdende Naam van God." Some theologians who do not explicitly use the term "public theology" for their work, nevertheless also address issues of oppression, discrimination and injustice (cf Metz 1980; Lamb 1982; Chopp 1987:120-138).

The reaction of the youth to all of this has been varied. The rebellion of the 1960 s and 1970 s has passed. Young people now contribute to society by finding work. Young and old are bound together by the fear of depleted resources, a destroyed environment and the weapons of mass destruction of world powers and "smaller" powers. Religion as personal experience of meaning and happiness has become the vogue again. It is a way of finding oneself in a confusing and alienating world. This is not the religion of churches and young people are not drawn to the church. A change in sexual mores has also taken place. Young people have a different view on sexuality and traditional roles. In and "inner-directed" society morality is guided by cultural norms. In a pluriform, pragmatic society this is no longer the case (see

Dingemans 1991:34). Neither the church ethics of the pre-World War II period, nor the revolutionary ethics of the 1960s and 1970s have prevailed. Groups and trendsetters now dictate a morality which is largely driven by self-interest (Dingemans 1991:34).

\subsection{The process of secularisation in modernity}

According to Janssen (2003:6) the cultural process which led to this state of affairs can be referred to as the split between "self" and "culture". In previous centuries people were bound to one geographic location for all of their lives. Now people from all over live and work together in the cities of the world. Before, the "self" was adapted to a one-dimensional world. These days such a simple "self" cannot be assumed any longer. The "self" has become a problem (see Baumeister 1987:163). People live as multi-dimensional "selves" who pass through flexible cultural environments. The "self" has become a complex construct consisting of pieces from different cultures. Cultures, in turn, are spread over diverse "selves" (Janssen 2003:6; see Hermans \& Kempen 1993, 1998:1111-1120). On all levels of life, flexibility is necessary for survival (cf 


\section{A public practical theological theory for religious education of secularised youth}

Sennett 2000). The effect of this on the youth is that they cannot imagine remaining in the same job with the same company for a lifetime. Some even have a problem with the idea of a permanent job of any sort. They also want to be flexible in their personal relationships (Janssen 2003:6). First sexual activity is taking place at an earlier age, whereas people are getting married later (cf Sanders 1999).

Yet, in the midst of all this, people are again and again creating institutions or forms of behaviour in order to find some stability in an unstable world. Janssen (2003:7) calls this seeming contradiction "het stabiliseren van onstabiliteit." Though many marriages end in divorce, people enter into subsequent marriages. Where such options are available, as in the Netherlands for instance, others prefer some kind of contract to the traditional marriage. As far as religion is concerned, young people tend to be eclectic. They gather elements from different religions and fuse them into a personal religion (cf Fuchs 1983:341-347). Janssen (2003:8) sees the reason for the increasing belief in reincarnation rather than in the Christian resurrection both equally difficult to prove scientifically - as the flexibility of the former. The Christian resurrection is bound up with the last judgement, which happens once and for all. Reincarnation provides more opportunities and therefore fits in better with the spiritual identity of the modern person.

Social scientists use terms such as "bricolage", "patchwork, "zap culture" and "meander culture" to describe the tendency of especially young people to create such temporary constructs for themselves and to be individualistic at all costs. Janssen (2003:9) refers to an Italian billboard stating "change lanes before your lane changes you" as a summary of this tendency of: "change religions before your religion changes you; change spouses before your spouse changes you".

\subsection{The religiosity of secularised youth}

In a recent study by Chipani, Osmer \& Schweitzer (2003) almost all the young people interviewed, distinguished between religion and spirituality.

For the most part, "religion" was identified with institutional forms of religion and "spirituality" with the individual's personal stance or moral/religious practice (e.g. an invidual's personal relationship with God or putting into action those things she/he believes). Several of the interviewees who do not participate in a religious community used this distinction to make the point that you do not have to be religious in order to be spiritual (e.g. hold a moral stance toward life or form a centered, healthy way of life). 
The question arises whether Christianity is still a meaningful option for modern and postmodern people. It has become difficult to imagine that these multidimensional "selves" lost in a continually changing multicultural context have a "Father in heaven" who knows them by the name, who sent "his Son" to die on the cross for their sins (Janssen 2003:11).

In some ways it seems that Christianity does remain an option for young people who show an interest in spiritual matters. Since 1977 European cities have been organizing ecumenical gatherings for young people during December. With the turn of the millennium 80000 young people gathered in Barcelona (Janssen 2003:11). Another example is Taizé, the monastery in France where, since the 1960s, young people have been gathering in great numbers from all over the world to praise and pray. The services are held in a large movable structure rather than in a permanent building. In this tent-like place of worship the uncoordinated religious experiences of the youth are coordinated by means of a well-organized togetherness without conditions (Janssen 2003:12).

In the aforementioned European study among young people it was found that they felt intimidated by the word "God". Asked whether they prayed to God only $11 \%$ of Dutch youth answered in the affirmative. For people above the age of 60 it was $42 \%$. When asked whether they have moments of prayer or meditation $61 \%$ answered yes. This does not differ much from the $68 \%$ of older people. The picture is similar in the rest of Europe (see Janssen, De Hart \& Den Draak 1990:99-107). The study indicates that only 39\% of Dutch youth belong to a church, which is the lowest of the sixteen countries researched. When it comes to individualized religious behaviour such as prayer, however, $82 \%$ of Dutch youth indicated that they pray, which places them third after Ireland and Italy. Therefore, even in countries where institutionalised religion is declining, the youth is still praying. Young people pray when confronted with problems concerning others. They ask for or hope for something or they meditate. They seek emotional help from God. They pray at night in bed with eyes closed and hands folded (Janssen, Prins, Baerveldt \& Van der Lans 2001:29-54). Most of these aspects are also found in traditional prayer: people pray when they experience difficulties, most pray to God and ask for help and the strength to deal with life (see Heiler 1920; cf Brown 1994). It is interesting to note when and where young people pray. In their hectic lives there is no time for prayer and meditation. In bed, just before falling asleep, they can be quiet and think about the day. Feelings of guilt and disappointment are processed. Resolutions and plans are made. Prayer fulfils an important psychological function for building identity (Janssen 2003:13). In psychological terms prayer can be seen as a mechanism for giving meaning 


\section{A public practical theological theory for religious education of secularised youth}

to what happened during the day, to accept what is given and to change what can be changed (Janssen 2003:14).

On the question of who God is, the Dutch youth used a great variety of words and images. It seemed as though they were inventing their own definitions as they went along. This corresponds with the Belgian study of Hutsebaut and Verhoeven (1991:59-73) who found that the images of God of a group of young people aged 12 did not correspond with their images at the age of 15. This is an indication that they do not have a shared vocabulary or set of images. In a Dutch study researchers found that the young people were not able give answers to the well-known questionnaire of Vergote \& Tamayo (1981) concerning images of God, since the question were meaningless to them (Mischke \& Wittenberg 1990). The research of Vergote \& Tamayo (1981; cf also Vergote, Tamayo, Pasquali, Bonami, Pattyn \& Custers 1969:7987) demonstrates a clear relationship between images people have of God and images of parental figures.

Building upon this research, another study shows that a Christian believer tends to "shape a self-concept that corresponds ... to some extent and in some sense to his or her image of Jesus" (see Francis \& Astley 1997:247-259). For the Dutch youth traditional God images have lost their credibility. They prefer vague, abstract conceptions of their own making. The situation in Germany is similar: "Unter den Kindern scheint es eine grosse Offenheit und Toleranz gegenüber andersgearteten Darstellungen zu geben. Sie gehen davon aus, dass es nicht nur eine einzige, richtige Darstellung geben kann" (Klein 2000:175). Hennie Pieterse (2003:1091; cf also Van der Ven, Dreyer \& Pieterse 1997a:840-836; 1997b:864-880) shows a similar trend in empirical findings on God images of Afrikaans speaking youth. They have a clear preference for the view which "emphasises Jesus' humanity" while they simultaneously accommodate various other images.

In a world of modernity and late modernity with the process of globalisation well on its way, the dominance of the various communication networks such as the internet and television, the influence of music, and the contact with others in the multicultural and multireligious contexts which is South Africa, Christians are overwhelmed by a pluralistic collage of ideas and beliefs ....

(Pieterse 2003:1091)

Janssen (2003:14) is of the opinion that the youth's personal meditation from the heart, searching for contact, should be taken seriously. He cites the example of the postmodern prayer one of the respondents: "I pray to God in 
whom I do not believe to help my friend who does believe, if God exists" (Pieterse 2003:1081-1105).

Our time has been characterized as a time of religions without God. Religiosity is free, self-chosen, individual, tentative, always moving and accidental. Traditional believers, on the other hand, experience their religion from a sense of duty, as bound to specific times and places, regular and in community. Modern believers have been described as "seekers" and traditionally socialised believers as "intrinsic believers" (Batson, Schoenrade \& Ventis 1993). Janssen (2003:15) sees the youth of today rather as "believers" than "belongers", more as seekers than as intrinsic believers. From a psychological perspective Batson et al (1993:364) see the "quest"-believer as more tolerant, open, socially inclined, less authoritarian and prejudicial than intrinsic believers. From a sociological perspective, however, religious institutions which are carried by intrinsic believers, are the ones to care for and help the oppressed in society in different ways. The seekers make little or no contribution. The reason for this could be that the "soft, symbolic violence" (see Bordieu \& Wacquant 1992:167) of an "intrinsic" culture-oriented lifestyle "forces" intrinsic believers to do their public duty. Secularised young people do not like power, history, institutions and grand narratives. They have no vested interests. They only have themselves and their own fragile personal stories. Listening to their stories in a reflexive way requires agency to transform modernity. According to Pieterse (2003:1091), the "empirical situation challenges our confessional tradition and compels us to think in a hermeneutical and dialectical way."

\section{A THEORY TO ENGAGE WITH THE FIELDS OF MODERNITY AND POSTMODERNITY}

\section{1 "The heretical imperative"}

In his book, The noise of solemn assemblies, the sociologist Peter Berger (1961) criticizes the Protestant churches in the United States of America. According to him, they are preaching a culture-religion rather than the transcendent gospel of Christ (Dorrien 2001:28-29). What this religion is in effect doing is to reinforce the existing social order. It has no critical or independent stance as far as society is concerned. The church secures its own position by affirming middle-class Americans and receiving their loyalty and support in return. The "Christian truth" was lost in this "bad faith" propagated by the churches. "There occurs a process of religious inoculation, by which small doses of Christianoid concepts and terminology are injected into consciousness ... By the time the process is completed the individual is 


\section{A public practical theological theory for religious education of secularised youth}

effectively immunized against any real encounter with the Christian message" (Berger 1961a:116). In his book, The precarious vision, Berger (1961b) argues that the mission of the church is not to teach people morality or how to live a "good", respectable life. Concurring with Bonhoeffer he pleads for the secularisation of Christianity, or a "religionless" Christianity. Secularisation helps to divest Christianity of its Westernised, "culturated" religion. Weber's description of such a culture-religion is "disenchantment" (Entzauberung) (see Berger 1961b:177). Only by demystifying (i.e. to secularise) such a religion, can churches be true to their real biblical message.

In his work, Invitation to sociology: A humanistic perspective, Berger (1963) points out how traditional sociology with its emphasis on the human condition, reinforces the "bad faith" of mainline religion. If determined by one's social environment, the individual has no choices and therefore also no responsibility. Berger counters this by placing the emphasis on freedom. Human beings need not be determined by society if they recognize the influence society has on them and realise that they always have a choice. They do, however, have the freedom not to choose their freedom and to allow themselves to be trapped in the human condition.

Together with Thomas Luckmann, Berger (Berger \& Luckmann 1966; Berger 1967) went beyond the prevailing sociological models of functionalism and structuralism to argue that human reality itself is a social construction and that the sociology of knowledge should focus on commonsense knowledge. Society is the product of human beings, but in turn shapes those who form it. Every social reality, including religion, can only be understood from its dialectical relationship with society (cf Dorrien 2001:30-31). In The sacred canopy Berger (1967) describes this dialectic as a process of externalisation, objectivation and internalisation. Externalisation is when human effort is given out into the world. Objectivation is when the result of human effort becomes a separate reality which in turn can confront the human beings who created it. Internalisation is when this objectified reality is subjectively taken in by human beings. "In this scheme, society is created through externalisation, it becomes an apprehended reality through objectivation, and the producing human subject becomes a product of society through internalisation" (Dorrien 2001:31).

Socialization is the process by which human creations such as customs and ideas are transmitted to the next generation. In this process the objectivised cultural meanings are taught by the older generation and accepted (internalised) by the younger generation. Religion has a socializing role. Religion also fulfils the function of providing meaning and order for human experiences. Dorrien (2001:32) interprets Berger's idea as follows: 
"The purpose of religion is to construct a sacred cosmos. Religion offers a protective canopy of transcendent legitimacy, meaning, and order to the precarious constructions that society calls 'reality'. The fate of any social order is therefore inevitably bound up with the fate of religion." The modern processes of secularisation and pluralisation endanger traditional Western religions because they erode the credibility of these religions. The future of religion in modernity is therefore precarious. In his work, $A$ rumour of angels (1969), Berger pleads for the liberation of theology from modern reality. Theology should again find "signals of transcendence" in the natural world, but should also be able to transcend this world. Religious experience for him is not mystical, but discovering the religious implications of everyday human experiences. The Bible is a record of such human experiences seen in a religious light (Berger 1969:84; cf Dorrien 2001:33).

Modernity brought relativism to the table. All religions are constructed human experience. In his book, The heretical imperative, Berger (1979) proposes that some aspects of Christianity will be retained and reformulated for the modern world, whereas others will have to be rejected. That is the "heretical imperative" (cf Dorrien 2001:34; Osmer \& Schweitzer 2003:37-38). One such untenable notion Berger identifies, is the idea that Christianity is based on an infallible, external authority. In order to fulfil the imperative the researcher needs to provide a theory of agency which does not lose sight of the complexity of modernity as the context of present-day youth.

\subsection{An agency theory}

The dialectic of structure and agency and the priority of agency in this bidirectional process, has been seen by Margaret Archer (1988:ix) as "the basic issue in modern social theory". Ten years earlier Dawe (1978:379) described it as follows: "Here, then, is the problematic around which the entire history of sociological analysis could be written: the problematic of human agency." Agency refers to individual human actors or collectivities which act. Human agents include "individuals as well as organized groups, organizations and nations" (Burns 1986:9). Though not organised, collective entities such as gender (male, female or same-sex groups), ethnic groups, age groups (e g youth or the elderly), social class groups (e g professional persons, blue-collar workers, etc), also act as agents in interaction with their structural fields or institutions. The structuration theory of Anthony Giddens (1984; cf Bernstein 1989:23) aims to integrate agency and structure. According to Giddens (1984:219): "Every research investigation in the social sciences or history is involved in relating action [agency] to structure ... there is no sense in which structure 'determines' action or vice versa." Agency and structure are two 


\section{A public practical theological theory for religious education of secularised youth}

sides of the same coin. All action involves structure and the other way around (cf Ritzer 2000:523).

Social actors consciously produce the conditions which enable their activity within their culture (Giddens 1984:2). According to Giddens' concept of "double hermeneutics" (Ritzer 2000:523), two set of "agents" are involved: social actors who engage with their structures, and social researchers (including practical theologians) who study this process of reflexive engagement.

Agents make a difference to their social world. Certainly the influence of actors is limited, but they do have choices and therefore can make a difference. Giddens (1989:256) is careful to avoid the idea that structure is something "objective", outside of human action, which impacts on people without them having agency. Giddens puts it as follows: "the moment of the production of action is also one of reproduction in the contexts of the day-today enactment of social life" (Giddens 1984:25-26). The understanding social scientists have of the world may influence the actors studied by these researchers. This means that the impact practical theologians could have on the world they are studying, could lead to distorted findings (Ritzer 2000:523). On the positive side it is also possible that researchers, because of their agency as social actors, can contribute to the process of healing and enhancement of the social world they are studying.

Like Peter Berger, Giddens is also "deeply concerned" (Ritzer 2000:526) with the "shattering impact of modernity" (Giddens 1989:301). From the perspective of "public theology" this condition of "disenchantment" (Entzauberung) or the absence of transcendence in everydayness, should be addressed. Whereas Jürgen Habermas regards the fading away of religious beliefs, norms and values as modernity's "unfinished project" (see Browning \& Francis Schüssler Fiorenza 1992; Osmer \& Schweitzer 2003: 48-60), Paul Ricoeur (cf Drewery, Winslade \& Monk 2000:251; Ricoeur [1989] 1995:306) sees the awakening of spirituality along the lines of the Jesus narrative as the way in which the Christian consciousness could take agency. In his contribution, "Pastoral praxeology, hermeneutics, and identity", Ricoeur (1995:306) refers to this as follows:

It is a problem of identity. It seems to me that this is also a problem for those concerned with pastoral ministry inasmuch as there is always the problem of the "who": Who is the actor? Who intervenes? One intervenes in relation to whom? ... It is in such reflection that the word "return" takes on meaning, as when I speak of returning to myself, that is, of a return to what I am doing, but also to myself, to the self. 
Giddens' agency theory provides theoretical support for "public practical theology" which focuses on "publics" as micro-fields in large cultural structures. Rather than concentrating on human societies as macro-structures (see Lenski, Nolan \& Lenski [1970] 1995), structuration theory emphasises "the orderings of institutions across time and space" (Giddens 1989:300). Giddens sees institutions as "clusters of practices" (Ritzer 2000:526) and identifies four of them: symbolic orders, political institutions, economic institutions, and law. However, to understand the impact of modernity on the "publics" in which present-day youth live, one has to move beyond the social structures which underlie the complexity of the social world. What Giddens refers to as "institutions" (and Osmer \& Schweitzer as "publics"), Pierre Bourdieu calls "fields" which are dialectically linked to "habitus". Bourdieu's (1984:483) theory aims to overcome the false opposition between objectivism and subjectivism, or as he formulates it, the "absurd opposition between individual and society" (cf Ritzer 2000:530).

"Habitus", according to Bourdieu, is the "mental or cognitive structures" by means of which people engage with their social world. The social world is perceived, understood, appreciated and evaluated through a series of internalised schemes. Through such schemes people both produce their practices and perceive and evaluate them (Ritzer 2000:533). Every person has a different habitus, depending on his or her position in the world. Those whose position is similar, such as a peer group like the youth, tend to have a similar habitus. Bourdieu (1977:72) describes habitus as the "dialectic of the internalisation of externality and the externalisation of internality" (cf Ritzer 2000:534). In this way habitus avoids having to choose between subjectivism and objectivism, to "escape from under the philosophy of the subject without doing away with the agent ... as well as from under the philosophy of the structure but without forgetting to take into account the effects it wields upon and through the agent" (Bourdieu \& Wacquant 1992:121-122). This avoidance of determinism distinguishes Bourdieu from other mainstream structuralists (Ritzer 2000:534). Habitus manifests itself in the common practices of everyday life, such as eating, walking, talking, praying, worshipping, singing.

"Field", in the theory of Bourdieu, is explained by Ritzer (2000: 535; cf Bourdieu \& Wacquant 1992:97) as follows: "The field is a network of relations among the objective positions within it ... The occupants of positions may be either agents or institutions, and they are constrained by the structure of the field. There are a number of semi-autonomous fields in the social world (for example ... religious [and] higher education), all with their own specific logics and all generating among actors a belief about the things that are at stake in a field." Participants follow strategies in order to maintain or improve their 


\section{A public practical theological theory for religious education of secularised youth}

positions. They utilise "the principle of hierarchization" for their own benefit (Wacquant 1989:40). In a field there is competition for economic, cultural, social and symbolic means. The field of (political) power is important because the hierarchy of power relationships structure all other fields (Ritzer 2000:535). According to Bourdieu the state is where symbolic violence takes place. This is "soft" violence - "violence which is exercised upon a social agent with his or her complicity" (Bourdieu \& Wacquant 1992:167). Symbolic violence is practiced indirectly and by means of cultural mechanisms. It differs from the more direct forms of social control. The educational system is one of the important systems practicing this form of violence (Ritzer 2000:536; cf Bourdieu \& Passeron [1970] 1990.)

According to Osmer \& Schweitzer public theology engages with audiences which exist in specific publics. My contention is that Bourdieu's agency theory, which pertains to the dialect between habitus and field, can provide a theoretical model for doing public theology. Osmer \& Schweitzer (2003:8-16) distinguish four publics: the individual person, the family, the church and the general public (including the state). This paper focuses on the youth among the general public outside of ecclesial structures. To address the absence of transcendence in the everydayness of the lives of young people, public practical theology's "unfinished project" should not be to judge the seekers among the youth or to reject the "fields" in which they live. This would be escaping reality. Seekers and researchers should rather become agents together in a reflexive process of demystifying "bad faith" in order to awaken a spiritual response to the Jesus narrative. A sceptical approach to modernity is that of Erik Erikson (in Strommen 1973:17) who believes

that our ruthless heritage of radical enlightenment will force an important segment of our youth to be human without illusion, naked with narcissism, loving without idealization, ethical without moral passion, restless without being classifiably neurotic, and political without lying.

An alternative approach would be that "[m]any adults join the youth in preferring:

a new emphasis on "being" rather than "doing"

a greater accent on feelings and experience

a desire for more opportunities to know one another in depth

greater sensitivity for suffering persons

greater interest in variety and experimentation.

(Strommen 1973:45) 
A characteristic of present-day youth is a tendency toward irrationalism: the feelings of the individual dictate how reality is seen and experienced. One's feelings need not be explained or justified to others (Dingemans 1991:35). Feelings are expressed in music, togetherness, sexuality, drugs and a mixture of religiosity (see Decker 1975:90). Religion has been privatised. Religious imagery is becoming increasingly individual and is interpreted subjectively. The creedal descriptions of faith by the church have been substituted with personal convictions. The church's formulation of faith in an ontological "personal God" creates the space for faith in a functional God "as Spirit" (see Dingemans 2000). In the same vein young people are spiritual, but have departed from the church. Young people are involved with religious experience, form their own images and ideas, but do not find themselves in the structures and norms of the church. The gap between institutionalised religion and the public religiosity of the youth is becoming wider (Dingemans 1991:36).

Vergote (in Dingemans 1991:37) describes religious experience as a sense of having contact with a "supernatural agency". It is an encounter with "another", not "talking to oneself". Being oneself while experiencing the transcendent, is to live an authentic life. According to Heidegger (in Collins \& Selina [1999] 2001:63), authentic identity does not manifest in Sein, but in Dasein: "It is not I myself who for the most part and on average am my Dasein, but the Others ... Dasein is subject to take-over bids by the Others. It exists as an 'I am' but also as an 'I-am-with-the-Others'" (see Ricoeur [1989] 1995:303-315). Sein and Dasein cannot be separated, because dialectic relationships cannot be broken. Sein pertains to objectified and empirical data (see Van der Ven 2000:56-57) and Dasein to what Gerben Heitink ([1998] 2000:73; cf 1999:25-41) calls "transendentiebesef" (a sense of transcendence - in other words, the spiritual dimension of being). Sein can be studied by means of the social sciences and Dasein by means of disciplines such as theology. Public theology is an interdisciplinary approach in which social theory and the theory of practical theology merge. Therefore, a theory of practical theology which would address the non-cognitive, perceptual experiences of present-day youth should be "public" in nature. Such a theory requires a method which operates in a multidisciplinary way.

\subsection{Theory, multidisciplinarity and method}

The practical theologian's work begins in an existing praxis which is the result of past theological and social scientific reflection. The aim is to arrive at an improved praxis by means of a new reflection of both theology and the social sciences. The question is how these two disciplines are brought together in 


\section{A public practical theological theory for religious education of secularised youth}

the practical theological method. Does theology dictate because it formulates the goal, or does social science dictate because it is best capable of insight into the praxis (see Dingemans 1991:22-23)? F H Kuiper's (1977:42) approach is "complementary": the social sciences take precedence during the analytical phase and theology takes over during the phase of planning. For both Rolf Zerfass (1974) and Riet Bons-Storm (1984) the two circles are always in play simultaneously. When a theological goal has been formulated, is immediately has to be clarified from a social scientific perspective.

The opposite is also true: if social scientific analysis has brought the researcher to the formulation of a goal or method, this has to be tested for its compatibility with theological intentions and possibilities. Theology does not exist in isolation, but in interaction with the praxis. So also transcendence exists not separate from, but in everydayness. Hans van der Ven opts for the method of interdisciplinarity. In his book, Kritische godsdienstdidactiek (Van der Ven 1982), he chooses an ideological critical approach to the praxis which brings him to an emancipatory pedagogy (cf also his book Education for reflective ministry [1998] about a reflexive pastoral theology for use by clergy in the Roman Catholic).

Concurring with Van der Ven (1990:117), Immink (2003:178) describes the relationship between practical theology and the social sciences as a "critical correlation." Critical for him means that practical theology defines the domain of research from the perspective of a theological understanding of the praxis. A theological theory will come to a different reconstruction of reality than the social sciences. In a theological reconstruction religion is not seen primarily as a social or psychological phenomenon, but as faith praxis. Theology reconstructs from the basis of theological theory (cf Schweitzer 1999:307-321; Immink 2003:182-183).

Immink (2003:192) is hesitant to give social theory equal weight to theology when "geloof in praxis" is at stake. According to Den Dulk (2003:127) this caution is due to the fact that Immink regards the Kantian heritage as the reason for secularisation. In Immanuel Kant's view the so-called "theoretical reason" (social stance) and "practical reason" (faith stance) could be distinguished, but never separated. Kant's dialectic distinction between social stance and faith stance has often led to three scholarly positions in theology: a social (empirical) emancipatory (theological) epistemology with the emphasis on the empirical (e $g$ Van der Ven); a theological theory in dialogue with the social sciences when deemed necessary, but always with the emphasis on theology (e g Immink). Den Dulk (2003:127) represents the dialectical position: 
Het is met de Verlichting, het is niet Kant, het is niet het empirisme [according to Immink the heritage of Kantian social philosophy] dat ons spreken over God in de benauwdheid heeft gebracht. Die druk van buiten herinnert ons slechts aan de druk, waaronder ieder christen van binnen uit gesteld wordt. Onze kennis staat nu eenmaal onder druk omdat we zelf in de deugen leven en onze kennis staat nog eens onder druk omdat we geconfronteerd worden met de verborgenheid van God. Wij misleiden onszelf als we menen direct over God te kunnen spreken.

\section{Fragments of Carl Friedrich's ([1949] 1977:70-115) translation of Kant's} (1783) Prolegomena zu einer jeden künftigen Metaphysik, die als Wissenschaft wird auftreden können, explains why the relationship between public practical theology and social theory should be seen as dialectic. It also explains why public religious education which will lead to the enhancement of the spirituality of secularized youth needs a multidisciplinary method:

On the one hand, we must not seek to extend beyond all bounds knowledge based on experience, for then nothing but mere [phenomenal] world remains for us to know. On the other hand, we must not seek to transcend the boundaries of experience and to judge things outside experience as things-in-themselves ... We are keeping to this boundary when we limit our judgment to the relation the world may have to a Being whose concept lies outside all that knowledge of which we are capable within this world. In this case we are not attributing to the Supreme Being itself any of the qualities by which we conceive the objects of experience and we are thus avoiding dogmatic anthropomorphism. But we do attribute these qualities to the relations of the Supreme Being to the world. We are thereby allowing ourselves a symbolical anthropomorphism which, as a matter of fact, only concerns the language and not the object ... When I say that we are impelled to regard the world as if it were the work of a supreme will and intellect, I am not really saying more than the following: As a watch, a ship, or a regiment is related to the craftsman, the shipbuilder or the general, so this world of sense, or all that constitutes the basis of this aggregate of phenomena, is related to the unknown, which I conceive, not according to what it is in itself, but according to what it is for me in regard to the world of which I am part ... An insight such as this is gained by analogy, not in the usual meaning of an imperfect resemblance of two things, but of a perfect resemblance of two relations between totally dissimilar things .... Hence, by means of an analogy such as this, I can give a relational concept of things absolutely unknown to me. For instance, as the promotion of the happiness of children is related to the love of parents, so the welfare of the human race is related to the unknown [quality] in God 
which we term love, not as though this unknown quality had the least resemblance to any human affection, but because we can conceive its relation to the world as similar to the relation that things of the world have to each other. But here the relational concept is a mere category; it is the concept of cause which has nothing to do with sense perception .... By means of this analogy there remains a conception of the Supreme Being which is adequately defined for our purposes, although we have left out everything that could determine this conception generally and in itself. For, we define this conception in respect of the world and therefore of ourselves and no more is necessary for us.

(in Friedrich 1977:105-106, 106; emphasis by Kant)

With regard to religious education, the developmental theorist, Jean Piaget (1997), describes his theory as "dynamic Kantianism" (cf also Piaget's [1973] Main trends in inter-disciplinary research). The stages of development of a child are characterised by the dynamic relationship between the biological and the environment. The goal or task of development is for the child to gain control of the environment and/or to change it. Human beings create their world. In the interaction between the development and the environment the "self" is formed. This is an ongoing process which ends only at death, but it is clear that an escalated development of the "self" does take place during the first eighteen years of a person's life. That is why developmental theorists are particularly interested in this period (Dingemans 1991:85). Such an approach has led to Dingemans' "pedagogy in context" and to Osmer and Schweitzer's "public religious education".

\section{RELIGIOUS EDUCATION FOR SECULARISED YOUTH}

If religious communities are to continue into the future, new members should be made. One way of doing this is educating the young to know and continue with the tradition. It is also important for traditions to be reformulated and reinterpreted in such a way that each new generation can find answers to the questions of their time and place. This ongoing transmission and reconstruction is what keeps traditions alive (Osmer \& Schweitzer 2003:xii). Churches seem to have difficulty persuading the youth that the tradition does in fact have significant meaning for their lives.

According to Osmer \& Schweitzer (2003:218), public practical theology has the potential to contribute to the common good and to responsible citizenship. However, practical theology will have a much better understanding of what is at stake in Christian religious education in relation to the public if the effect of modernity is taken into account. While the focus of practical theology 
is the church, "its task also includes a public dimension and a broader responsibility to society as a whole. Practical theology must take into account the social, cultural, and political situation - a situation it must analyze, and must also address" (Osmer \& Schweitzer 2003:218).

Some American religious educators have adopted the term paideia to indicate the twofold vision of Christian education: discipleship and citizenship. The German term which describes similar aspects of Christian education, is kirchliche Bildungsverantworung (Osmer \& Schweitzer 2003:218). The term paideia goes back to L A Cremin's 1976 work on public education where paideia is described as the "social, political, or ethical aspiration" of a society (Cremin 1976:39; cf Osmer \& Schweitzer 2003:223). This idea has recently been connected with the notion of a "public church" (see Seymour, O'Gorman \& Foster 1984; Fowler 1990:63-69). Religious education should again take up its role in public life: "Education must be broadly seen in its variety of cultural manifestations, religion must be seen as the possibility for infusing transcendence into cultural life, and church education must be seen at the intersection of the cultural images and religious images that form persons and cultural life" (Seymour, O'Gorman \& Foster 1984:29).

Fowler (1990:63-69) sees the task as preparing children, adolescents and adults for becoming good citizens who are committed to the common good on the grounds of their Christian values and faith. The ideal of equal rights for all and policies of non-discrimination call for a neutral state and education system. The question is whether this completely excludes religious influences on public education. Osmer and Schweitzer (2003:226-227) respond as follows: "The two most important reasons for rejecting the idea of a religiously neutral education are the insufficiency of moral education alone and the negative effects of divorcing religion from education." Such negative effects are, among others, religious fundamentalism and fanaticism. Religious conflict can only become worse if there is no understanding of the beliefs and convictions of others. This kind of knowledge and understanding can be brought about in public education which supports dialogue. Globalisation is another reason for encouraging knowledge and understanding of other religions, since people increasingly come into contact with beliefs and lifestyles which differ from theirs.

Public practical theology and Christian religious education should focus on helping Christians to hold on to their own faith while making sense of the many different influences and ideas surrounding them. Such an agency will flow spontaneously when the presence of transcendence in everydayness is not only experienced as ordinary, but is consciously kept awake in oneself so that encounters with others enhance their spirituality. 


\section{A public practical theological theory for religious education of secularised youth}

\section{ENHANCING TRANSCENDENCE IN EVERYDAYNESS}

Human nature includes a spiritual dimension: "Het menselijke bestaan heeft ... een geestelijke zijde" (Immink 2003:32). Spirituality forms part of a person's habitus. Everydayness pertains to the fields in which a person exists. To separate transcendence and eveydayness is to break the dialectic between habitus and field. If, for instance, the established church rejects seekers because it cannot accept their postmodern publics (fields), that amounts to an attempt to break the dialectic. Theoretically it is impossible to break a dialectic relationship. However, this does not mean that either the habitus or the fields of seekers are condoned or justified even if they contradict the essence of the Jesus narrative. The task of the practical theologian is rather to enhance the spiritual dimension of seekers, as they exist in their fields.

According to the anthropologist and scientist of religion, Mircea Eliade (1987), people live in "profane time" (which can be depicted linearly because it encompasses the time from birth to death - i e ordinary, "historical" time). People simultaneously live in "sacral time" which manifests during religious events in their lives. Transcendence ("sacral time") is cyclical: it is recurring and traverses everydayness ("profane time"). The secular present is filled with the sacral past (cf Eliade 1975; see Van Aarde 2003). Sensitivity is needed for the qualitative difference between postmodern and modern "spiritualities", much as premodern "mythical" and modern ways of knowing/living differ (cf Segal 1999:81-84).

This paper has highlighted the spirituality of present-day "seekers" among the youth. They have developed an alternative to the "bad-faith" of the so-called "intrinsic believers" whose habitus is dialectically bound to their "modernised" and "Western culturated" fields. Congregational catechesis could still be an appropriate religious educational model for this modern context. Modern "logical thinking" is intrinsically adapted to the empirical reality to the extent that people "imitate the successiveness of objectively real things, so that the images inside our mind follow one another in the same strictly causal sequence as the events taking place outside it" (Jung 1967:11). Therefore, an ontological experience of God and "scholastic" religious education may still be appropriate for the "intrinsic believers" among the youth.

However, in order to engage with the "seekers", a public practical theological model which takes the spirituality of the "general audience" seriously, is needed. However, to a certain extent "seekers" are also products of the modern world. The youth mirrors the habitus of adults (for this aspect in the education of youth in antiquity see Kleijwegt 1991:126-130) - sometimes in a more intensified form. Present-day young people have departed from the 
"soft violence" of modernism and have entered a postmodern world. Their spirituality does not represent a return to premodern mythical thinking, but there are similarities. Carl Jung's ([1956] 1967:17) explanation of a premodern mythical way of knowing/living as spontaneous, associative and "directionless" also applies to the habitus of postmodern "seekers". In the three dimensional premodern worldview (heaven above, the earth below and the waters beneath the earth) external forces determine all aspects of people's lives, for better or for worse. These active forces are never absent and influence both human lives and nature. In the modern era this worldview was substituted with a "scientific" one (see Van Aarde 2003). However, as Joseph Campbell (1972:13) states in his book, Myths to live by, transcendence in everydayness "can never be displaced by the findings of science, which relate rather to the outside world." In the paradigm of a three dimensional worldview, the dualistic distinction between a "supernatural" and a "natural" world, did not apply (cf Saler 1977:46). Everydayness did not only include the "natural" (as seen from a modern perspective), but also the "spiritual": the world of God, angels, miracles, diviners, prophets, and magical powers. In the dualist scientific worldview the "supernatural" and the "natural" are increasingly treated as separate. In the modern paradigm the "supernatural" (e g God) is understood as being part of history (the transcendent enters into history from time to time), not manifesting through history (i.e. being constantly present). From a premodern perspective transcendence forms part of natural processes. Present-day postmodern perspectives are similar. "Intrinsic believers" would, for instance, appeal to the "supernatural" when "natural" circumstances are experienced as either threatening or as abundantly good (from time to time). For "seekers", on the other hand, the transcendent is "never absent" and its influence on human life and nature is constant.

In order to take agency in a process of enhancing the religious habitus of "seekers", public practical theologians reflexively engage with their lifestories. While interacting with "seekers", theologians will always have the foundational narrative of Christianity in mind. This does not mean that theology takes precedence over the insights of the social sciences (see Immink's 2003:157 evaluation of Dingemans' emphasis on the "Jesus narrative"). Because of the reflexive mode of the interaction, the worlds of both partners in the conversation will "rub off" on the other. The Jesus narrative may then become the foundational narrative for both (cf McGrath 1990:35).

Dingemans (1996:48) formulates the foundational role of the Jesus narrative as follows: "Het praktisch handelen van christenen wordt in principe aangestuurd door het evangelie van Jezus Christus, zoals dat is overgeleverd 


\section{A public practical theological theory for religious education of secularised youth}

via teksten van het verleden, die voor het heden worden geherinterpreteerd". For Hans van der Ven (1990:47) the interpretation of the text is not "schriftgeleerdheid" but "geëngageerd handelen". In his book, Ecclesiologie in context, Van der Ven (1993:65) therefore pleads that the church will take up its public responsibility for those inside and outside ecclesial structures. Engagement with people and their social needs necessitates engagement with biblical narratives. Immink (2003:159) explains Van der Ven's position as follows: "Werken met daklozen, asielzoekers, buitenlanders en randgroepjongeren is ondenkbaar ... zonder het vertellen, interpreteren en ophalen van verhalen."

Engagement with the Jesus narrative results in authentic Christian identity even if a person exists outside the ecclesial field of creedal Christianity. Everydayness without transcendence results in existential poverty. This could be the case for the "bad faith" of both the "intrinsic believer", and the secularised "seeker" who regards the demise of Christianity as the "unfinished task" of modernity. Everydayness without transcendence is seeking existential meaning in culture which is permeated by either modern or postmodern values. In Heidegger's language, "culturated existence" is to find meaning in Sein rather than in Dasein. However, authentic Christian identity does not manifest in conformism to cultural duties (Sein) enforced by the "soft symbolic violence" of either ecclesial or secular conventions. Rather, when engaging with the Jesus narrative (Dasein), the Christian absorbs the spirituality inherent in the gospel. Such a spirituality forms the essence of "being-with-the Others" (cf Ricoeur 1991:69; 1992; Van den Hengel 1994:458480), a life in which transcendence manifests in everydayness.

\section{Works consulted}

Archer, M 1988. Culture and agency: The place of culture in social theory. Cambridge: Cambridge University Press.

Batson, C D, Schoenrade, P \& Ventis, L 1993. Religion and the individual: A socialpsychological perspective. New York: Oxford University Press.

Baumeister, R 1987. How the self became a problem: A psychological review of historical research. Journal of Personality and Social Psychology 52.

Becker, J, De Hart, J \& Mens, J 1997. Secularisatie en alternatieve zingeving in Nederland. Rijswijk: sociaal en Cultureel Planbureau.

Becker, J \& Vink, R 1994. Secularisatie in Nederland 1966-1991. Rijswijk: Sociaal en Cultureel Planbureau.

Bell, D 1960. The end of ideology: On the exhaustion of political ideas in the fifties. New York: The Free Press.

Benson, P \& Eklin, C (eds) 1990. Effective Christian education: A national study of Protestant congregations: A report for the Evangelical Lutheran Church in America. Minneapolis, MN: Search Institute. 
Berger, P L 1961a. The noise of solemn assemblies: Christian commitment and the religious establishment. Garden City, NY: Doubleday.

Berger, P L 1961b. The precarious vision: A sociologist looks at social fictions and the Christian faith. Garden City, NY: Doubleday.

Bernstein, R J 1989. Social theory as critique, in Held, D \& Thompson, J B (eds), Social theory of modern societies: Anthony Giddens and his critics, 19-33. Cambridge: Cambridge University Press.

Bernts, A P J 1995. Meer stem voor jongeren: Een onderzoek naar jongerenkoren, religiositeit en kerk. Nijmegen: ITS.

Bons-Storm, R 1984. Kritisch bezig zijn met pastoraat: Een verkenning van de interdisciplinaire implicaties van de Praktische Theologie. 's-Gravenhage: Boekencentrum.

Bourdieu, P 1977. Outline of a theory of practice. Cambridge: Cambridge University Press.

Bourdieu, P 1984. Homo academicus. Stanford, CA: Standford University Press.

Bourdieu, P \& Passeron, J-C [1970] 1990. Reproduction in education, society and culture. London: Sage.

Bourdieu, P \& Wacquant, L J D 1992. The purpose of reflexive sociology (The Chicago Workshop), in Bourdieu, P \& Wacquant, LJ D (eds), An invitation to reflexive sociology, 61-115. Chicago, IL: University of Chicago Press.

Brown, $L$ 1994. The human side of prayer: The psychology of prayer. Birmingham, Ala: Religious Education Press.

Browning, D 1991. A fundamental practical theology: Descriptive and strategic proposals. Minneapolis, MN: Fortress.

Browning, D \& Schüssler Fiorenza, F (eds) 1992. Habermas, modernity and public theology. New York: Crossroad.

Burns, T R 1986. Actors, transactions, and social structure: An introduction to social rule system theory, in Hummelstrand, $U$ (ed), Sociology: The aftermath of crisis, 8-37. London: Sage.

Campbell, J 1972. Myths to live by. New York: Bantam.

Chipani, D, Osmer, R \& Schweitzer, F 2003. Youth, culture and globalization: A report of research in process, in Couture, P D \& Miller-McLemore, B J (eds), Poverty, suffering and HIV-Aids: International Practical Theological perspectives. Cardiff: Cardiff Academic Press.

Chopp, R S 1987. Practical Theology and liberations, in Mudge, L S \& Poling, J N (eds), Formation and reflection: The promise of Practical Theology, 120-138. Philadelphia, PA: Fortress.

Coleman, J S 1968. s v Modernization. International Encyclopedia of the Social Sciences 10.

Collins, J \& Selina, H [1999] 2001. Introducing Heidegger. Cambridge: Icon Books.

Cremin, L A 1976. Public education. New York: Basic Books.

Dawe, A 1978. Theories of social action, in Bottomore, T \& Nisbet, R (eds), A history of sociological analysis, 362-417. New York: Basic Books.

De Chateaubriand, F-R 1802. Génie du christianisme. Ille partie, livre 5.

De Hart J 1994. Jongeren na die middelbare school: Levensbeschouwelijke opvattingen, waardeoriëntaties en sekseverschillen. Kampen: Kok.

Dekker, G, De Hart, J \& Peters, J 1997. God in Nederland 1966-1996. Amsterdam: Anthos. 
Den Dulk, M 2003. Positiekeuze van een praktisch theoloog. Theologia Reformata 46(2), 122-129.

Dingemans, G D J 2000. De stem van de Roepende: Pneumatologie. Kampen: Kok.

Dingemans, G D J [1986] 1991. In de leerschool van het geloof: Mathetiek en vakdidaktiek voor catechese en kerkelijk vormingswerk.

Dingemans, G D J 1996. Manieren van doen: Inleiding tot de studie van het praktische theologie. Kampen: Kok.

Dorrien, G 2001. Berger: Theology and sociology, in Woodhead, L (with Heelas, P \& Martin, D) (eds), Peter Berger and the study of religion. London: Routledge.

Drewery, W, Winslade, J \& Monk, G 2000. Resisting the dominating story: Toward a deeper understanding of narrative therapy, in Neimeyer, R A \& Raskin, J D (eds), Constructions of disorder: Meaning making frameworks for psychotherapy, 243-263. Washington, DC: American Psychological Association.

Eisenstadt, S N 1966. Modernization: Protest and change. Englewood Cliffs, NJ: Prentice Hall.

Eliade, M 1975. Rites and symbols of initiation: The mysteries of birth and rebirth, $\operatorname{tr}$ by W R Trask. New York: Harper \& Row.

Eliade, M 1987. De magie van het alledaagse: De transcendentie van het dagelijks leven, tr by $\mathrm{H}$ Andrews. Katwijk: Srvire.

Felling, A, Peters, J \& Schreuder, O 1991. Dutch religion: The religious consciousness of the Netherlands after the cultural revolution. Nijmegen: ITS.

Fowler, J W 1987. Faith development and pastoral care. Philadelphia, PA: Fortress.

Fowler, J W 1990. Reconstituting paideia in public education, in Palmer, P J, Wheeler, B G \& Fowler, J W (eds), Caring for the commonweal: Education for religious and public life, 63-69. Macon, Ga: Mercer University Press.

Fowler, J W 1991. Weaving the new creation: Stages of faith and the public church. San Francisco, CA: Harper.

Francis, L J \& Astley, J 1997. The quest for the psychological Jesus: Influences of personality on images of Jesus. Journal of Psychology and Christianity 16(3), 247-259.

Friedrich, C J [1949] 1977. The philosophy of Kant, edited with an introduction by C J Friedrich. New York: The Modern Library.

Fuchs, W 1983. Jugendliche Statuspassage oder individuierte Jugendbiographie? Soziale Welt, 341-347.

Giddens, A 1984. The constitution of society: Outline of the theory of structuration. Berkeley, CA: University of California Press.

Giddens, A 1989. A reply to my critics, in Held, D \& Thompson, J B (eds), Social theory of modern societies: Anthony Giddens and his critics, 249-301.

Cambridge: Cambridge University Press.

Habermas, J 1981. Modernity versus postmodernity. New German Critique 22, 3-14.

Habermas, J 1987. The philosophical discourse of modernity: Twelve lectures. Cambridge, MA: MIT Press.

Hermans, H \& Kempen, H 1993. The dialogical self: Meaning as movement. San Diego, CA: Academic Press.

Hermans, $\mathrm{H}$ \& Kempen, $\mathrm{H}$ 1998. Moving cultures: The perilous problems of cultural dichotomies in a globalizing society. The American Psychologist 53(10), 1111-1120. 
Heiler, F 1920. Das Gebet: Eine religionsgeschichtliche und religionspsychologische Untersuchung. München: Reinhardt.

Heitink, G 1999. Praktische theologie in de context van de moderniteit: Een overzicht. Nederlands Theologische Tijdschrift 53, 25-41.

Heitink, G [1998] 2000. Pastorale zorg: Theologie, differentiatie, praktijk. 2e druk. Kampen: Kok. (Handboek Praktische Theologie.)

Hoge, D 1981. Converts, dropouts, returnees: A study of religious change among Catholics. New York: Pilgrim.

Hoge, D R, Johnson, B \& Luidens, D A 1994. Vanishing boundaries: The religion of mainline Protestant baby boomers. Louisville, KY: Westminster Press.

Huber, W 1979. Kirche. Stuttgart: Kreuz.

Huber, W 1998. Kirche in der Zeitenwende: Gesellschaftlicher Wandel und Erneuerung der Kirche. Gütersloh: Bertelsmann Stiftung.

Hutsebaut, D \& Verhoeven, D 1991. The adolescents' representation of God from age 12 until age 18: Changes or evolution? Journal of Empirical Theology 4, 59-73.

Immink, F G 2003. In God geloven: Een praktisch-theologische reconstructie. Zoetermeer: Meinema.

Janssen, J 1998. The Netherlands as an experimental garden of religiosity: Remnants and renewals. Social Compass 45(1), 101-113.

Janssen, J 2003. De jeugd, de religie en de toekomst: Een complexe verhouding. Praktische Theologie 30(1), 3-23.

Janssen, J, Hart, J \& Den Draak, C 1990. A content analysis of the praying practices of Dutch youth. Journal for the Scientific Study of Religion 29, 99-107.

Janssen, J \& Prins, M 2000. Let's reinvent the gods. The religion of Dutch youth. Archives de Sciences Sociales des Religions 109, 31-48.

Janssen, J, Prins, M H, Baerveldt, J C \& Van der Lans, J M 2001. The structure and variety of prayer: An empirical study of Dutch youth. The Journal of Empirical Theology 13(2), 29-54.

Jung, C G [1956] 1967. Symbols of transformation: Collected works, vol 5. $2^{\text {nd }}$ ed. Princeton, NJ: Princeton University Press.

Kleijwegt M 1991. Ancient youth: The ambiguity of youth and the absence of adolescence in Greco-Roman society. Amsterdam: J C Gieben.

Klein, S 2000. Gottesbilder von Mädchen: Bilder und Gespräche als Zugänge zur kindlichen religiösen Vorstellungswelt. Stuttgart: Kohlhammer.

Kosmin, B, Mayer, E \& Keysar, M 2001. American Religious Identification Survey 2001. New York: University of New York.

Kuiper, F H 1977. Op zoek naar beter bijbels onderwijs. Amsterdam: Radopi.

Lamb, M 1982. Solidarity with victims. New York: Crossroad.

Marty, M E 1981. The public church: Mainline, Evangelical, Catholic. New York: Crossroad.

McGrath, A E 1990. The genesis of doctrine: A study in the foundation of doctrinal criticism. Grand Rapids, MI: Eerdman

Metz, J B 1980. Faith in history and society. New York: Crossroads. 
Mischke, K \& Wittenberg, M 1990. Godsbeelden: Een analyse op een steekproef van Nederlandse studenten met gebruikmaking van de Semantic Differential Parental Scale (SDPS) van Tamayo \& Vergote. Intern rapport. Nijmegen: Katholieke Universiteit Nijmegen. Vakgroep Cultuur- en Godsdienstpsychologie.

Osmer, R \& Schweitzer, F 2003. Religious education between modernization and globalization: New perspectives on the United States and Germany. Grand Rapids, MI: Eerdmans.

Oswald, R \& Leas, S 1987. The inviting church: A study of new member assimilation. New York: Alban Institute.

Palmer, P J 1981. The company of strangers: Christians and the renewal of America's Public life. New York: Crossroad.

Piaget, J 1973. Main trends in inter-disciplinary research. London: Allen \& Unwin.

Piaget, J 1997. The moral judgment of the child, tr by M Gabain. New York: Free Press.

Pieterse, H J C 2003. A profile of the belief in Jesus and salvation among the Afrikaans speaking Christian youth. HTS 59(4), 1081-1105.

Ricoeur, P [1989] 1995. Pastoral praxeology, hermeneutics, and identity, in Ricoeur, $P$ 1995, Figuring the sacred: Religion, narrative and imagination, tr by $D$ Pellauer, ed by M I Wallace, 303-315. Minneapolis, MN: Fortress.

Ricoeur, P 1991. The task of hermeneutics, in Ricoeur, P, From text to action: Essays in Hermeneutics, II, tr by K Blamey \& J B Thompson, 53-74. London: Athlone Press.

Ricoeur, P 1992. Oneself as another. London: University of Chicago Press.

Ritzer, G [1983] 2000. Sociological theory. New York: McGraw-Hill.

Roof, W C \& McKinney, W 1987. American mainline religion: Its changing shape and future. New Brunswick, NJ: Rutgers University Press.

Saler, B 1977. Supernatural as a Western category. Ethos 5, 31-53.

Sanders, J 1999. De kunst van het beminnen: Relatievorming en scheiding. Nijmegen: Nijmegen University Press.

Schweitzer, F 1996. Die Suche nach eigenem Glauben: Einführung in die Religionspädagogik des Jugendalters. Gütersloh: Gütersloher Verlaghaus.

Schweitzer, F 1999. Practical Theology, contemporary culture, and the social sciences - interdisciplinary relationships and the unity of practical theology as a discipline, in Schweitzer, F \& Van der Ven, J A (eds), Practical Theology: International perspectives, 307-321. Frankfurt am Main: $P$ Lang.

Segal, R A 1999. Theorizing about myth. Amherst, MA: University of Massachusetts Press.

Sennett, R 2000. De flexibele mens: Psychogram van de moderne samenleving. Amsterdam: Biblos.

Seymour, J L, O'Gorman, R T \& Foster, C R 1984. The church in the education of the public: Refocusing the task of religious education. Nashville, TN: Abingdon.

Strommen, M P 1973. Bridging the gap: Youth and adults in the church. Minneapolis, MN: Augsburg Publishing House.

Ter Schegget, G H 1981. Theologie en ideologie: Een aanzet tot verantwoordelijk theologiseren onder vervreemdende maatschappelijke verhoudingen. Baarn: Ten Have. 
Van Aarde, A G 2003. Theorizing about myth. Acta Patristica et Byzantina 14, 245265.

Van den Hengel, J 1994. Paul Ricoeur's Oneself as another and Practical Theology. ThS 55, 458-480.

Van der Linden, F J 1989. Groot worden in een klein land: Feiten en cijfers uit het onderzoek naar de leefwereld van jongeren tussen 12 en 21 jaar. Nijmegen: ITS.

Van der Ven, J A 1990. Entwurf einer empirischen Theologie. Kampen: Kok.

Van der Ven, J A 1993. Ecclesiologie in context. Kampen: Kok.

Van der Ven, J A 2000. Pastoraal perspectief: Vorming tot reflektief pastoraat. Kampen: Kok. (Theologie \& Empirie.)

Van der Ven, J A \& Biemans, B 1994. Religie in fragmenten: Een onderzoek onder studenten. Weinheim: Deutscher Studien Verlag.

Van der Ven, J A, Dreyer, J S \& Pieterse, H J C 1997a. Belief in God among South African youth. HTS 58(3), 840-863.

Van der Ven, J A, Dreyer, J S \& Pieterse, H J C 1997b. Belief in God among South African youth and its relation to their religious socialization and praxis. HTS 58(3), 864-880.

Vergote, A \& Tamayo, A 1981. The parental figure and the representation of God. The Hague: Mouton.

Vergote, A, Tamayo, A, Pasquali, L, Bonami, M, Pattyn, M-R, \& Custers, A 1969. Concept of God and parental images. Journal of the Scientific Study of Religion 8, 79-87.

Wacquant, L J D 1989. Towards a reflexive sociology: A workshop with Pierre Bourdieu. Sociological Theory 7, 26-63.

Wilson, A N 2000. De begrafenis van God: De ondergang van het geloof in de westerse beschaving. Amsterdam: Prometheus.

Zerfass, R 1974. Praktische Theologie als Handlungswissenschaft, in Klostermann, F \& Zerfass, R (Hrsg), Praktische Theologie heute. München: Kaiser Mainz. 